\title{
Histological Changes in the Organs and Tissues of the Gobiid Fishes throughout their Life-span-VIII Seasonal Changes in the Thymus of Four Species of Gobies*1
}

\author{
Eimitsu TAMURA*2 and Yoshiharu HonMA*3
}

(Received February 23, 1977)

\begin{abstract}
In order to determine the specific factor which provokes the seasonal changes in the thymic activities of gobies four selected species were examined histologically throughout their life-span.

Peak thymic enlargement in all species examined is seen in May to July, whereas the breeding season of these species takes place in early spring or summer. The cyclic patterns in the thymic activities of gobiid fishes may coincide with the annual fluctuation in the duration of day light rather than with cyclic changes in breeding. The greatest relative growth of the thymus occurs in the larval or under-yearling gobies. After larval stage a gradual involution of the thymus occurs day by day. This change differs from that of adult fish which show cyclic variation.

In Chasmichthys gulosus and Acanthogobius flavimanus the hyperplasia of the parenchyma and increase in the amount of connective tissue and epithelial cells take place in parallel with the enlargement of thymus. Hassall's corpuscles and their allied structures, and formation of follicles are demonstrated in the enlarged thymus.
\end{abstract}

It is well known that the mammalian thymus develops rapidly during the early time of the life-span, and a heavy involution or final disappearance occurs until the sexual maturity. The same is encountered in the annual fish, such as the Ayu and ice-goby, while the cyclic change is seen in the thymic activities of other species, such as the flathead and forktongue gobies which are able to spawn several times during their life-span of several years. However, a gradual reduction of the thymus with an increase in age was noticed in these fishes. ${ }^{1-5)}$ A possible relationship between the thymic function and hemopoiesis of the spleen and head kidney, in addition to the activity of interrenal (adrenal) gland, was postulated in the forktongue goby and flathead goby. ${ }^{3-4}$ ) These results may suggest that there is another undiscovered function in the thymus.

In order to elucidate the possible relationship between the thymic function and hemopoietic organs and/or endocrine organs of fish, further studies were planned to emphasize the causal leading factor or trigger of thymic activity. Then four species of gobies consisting of two groups of related or paired species were selected as materials and examined on the cyclic changes of their thymuses.

*1 Contributions from the Sado Marine Biological Station, Niigata University, No. 277.

*2 Niigata Senior High School, Sekiya, Niigata, 951 Japan (田村栄光：新潟高等学校).

*3 Sado Marine Biological Station and Department of Biology, Faculty of Science, Niigata University, Niigata, 950-21 Japan (本間義治：新潟大学理学部). 


\section{Material and Methods}

Two related gobies, Chasmichthys dolichognathus and C. gulosus were collected in the rocky shore in the vicinity of the Sado Marine Biological Station of Niigata University located at the northwestern coast of Sado Island. Other two species, Acanthogobius flavimanus and A. lactipes were obtained in Miomote River and Ishikawa River both in Murakami City located at the northern part of Niigata Prefecture facing the Japan Sea. These species, consisting of larval to adult fish, were collected at monthly intervals throughout the year of March 1974 to February 1975. In order to estimate the age of the fish, 166 specimens of $C$. gulosus, 238 of C. dolichognathus, 446 of A. flavimanus, and 96 of $A$. lactipes were used, and for histological examination, 110, 116, 197 and 65 specimens were employed, respectively.

The block including thymus was fixed in Bouin's solution, dehydrated by a series of methanol, embedded in wax, cut serially 5 to $8 \mu$ thick, stained with hematoxylin-eosin, azan trichrome, periodic acid Schiff's reaction (PAS) or aldehyde fuchsin (AF), and observed under the light microscope.

\section{Results}

[1] It is considerably difficult to identify and discriminate between the larval and juvenile $C$. dolichognathus and $C$. gulosus, because of the similar features of external morphology and habitat. However, the shape of thymus differs each other, in addition to the brain pattern and the shape of kidney. Moreover, the breeding season of $C$. gulosus extends from January to April, while that of $C$. dolichognathus begins and ends one month later (February to May) than in C. gulosus. Accordingly, the adult of $C$. gulosus caught in May to June are all spent fish, and two groups of fish consisting of one-year- and two-year-olds are also found in June (Textfig. 1). The juvenile fish measuring about $30 \mathrm{~mm}$ in length are then collected in July. On the other hand, the spent adult of $C$. dolichognathus are obtained in June to July, and larval fish, $10 \mathrm{~mm}$ in length, are already caught in June. Therefore, the frequency distribution of the body length of this species in June may correspond to the under-yearling and one-year-old (yearling) fish, respectively (Textfig. 1). A small number of larger fish, measuring more than $55 \mathrm{~mm}$ in length, caught in winter season (January to March) seem to be the old and senile one.

In C. gulosus, the individual, more than $45 \mathrm{~mm}$ in length, may reach its sexual maturity at the stage of one full year, while in $C$. dolichognathus, may reach sexual maturity in about $30 \mathrm{~mm}$ in length.

C. gulosus The relative size of the thymus in this fish is larger than that in C. dolichognathus, and in May to June, it attains $5 \mathrm{~mm}$ in length and $3 \mathrm{~mm}$ in depth in the most enlarged stage. On the other hand, the largest thymus of the C. dolichognathus in June 

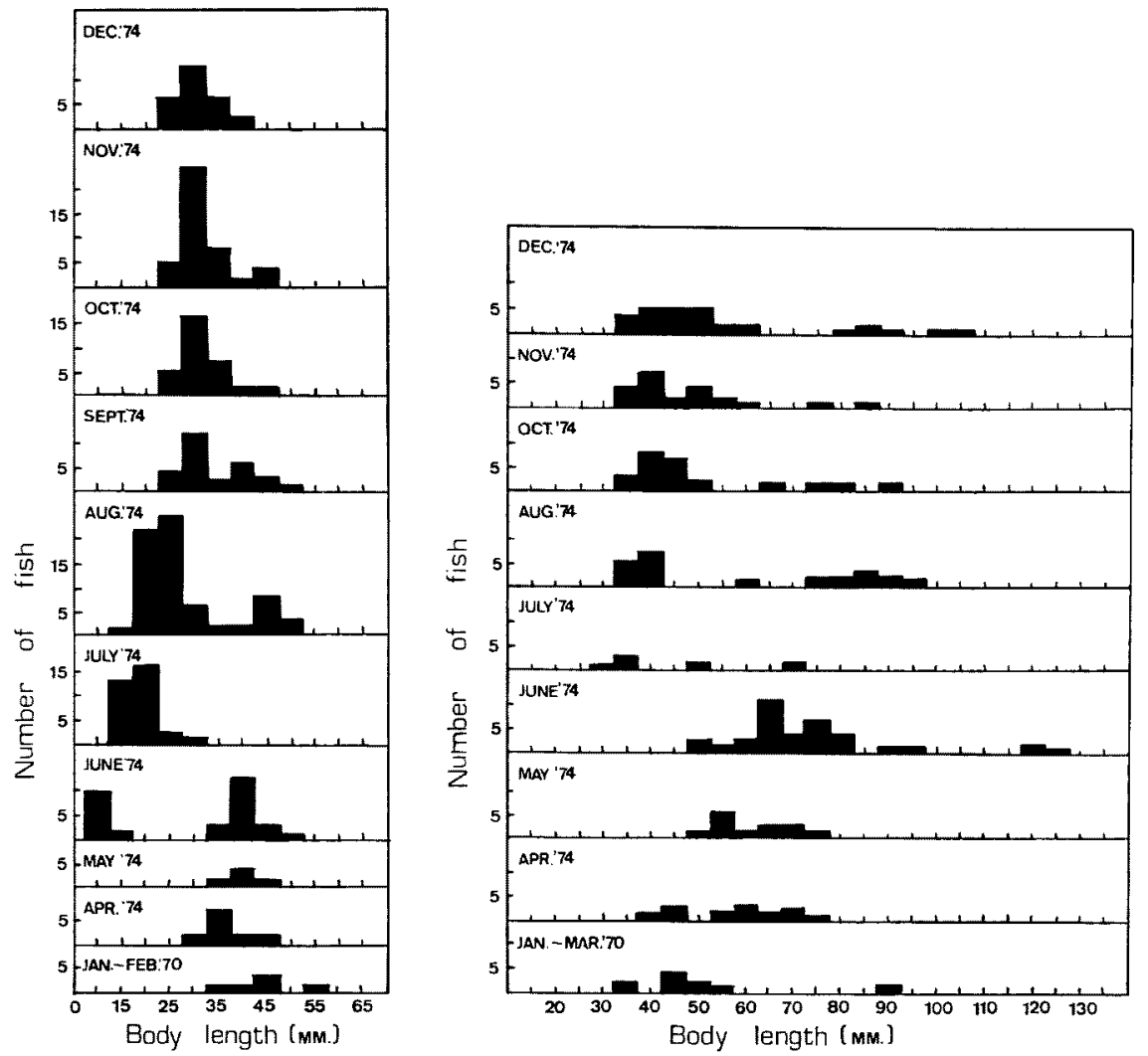

Fig. 1. Monthly change of frequency distribution of the body length of Chasmichthys dolichognathus and $C$.gulosus, caught in the rocky beach of Sado Island in the Japan Sea.

to July is $2.5 \mathrm{~mm}$ in length and $1 \mathrm{~mm}$ in depth.

The thymic parenchyma of mature C. gulosus caught in April is about $350 \mu$ in thickness, and a remarkable enlargement of about $650 \mu$ in thickness, associated with an increase in the number of small lymphocytes is encountered in the spent adult in May to June. An indication of follicular formation in the parenchymatous tissue and increase in the amount of connective tissue near the periphery of vascular wall are noticed in this stage (Plate 1, Fig. 1 a-b). Further, it is noticed that the corpuscles similar to the Hassall's corpuscles are scattered here and there. After July, a gradual diminution in the thymic parenchyma occurs, and further decrease in the small lymphocytes is marked. The specimen in October is very thin, about $150 \mu$ in depth. The connective tissue components in and near the basal part of thymus and periphery of the vascular wall develop well (Pl. 1, Fig. 2). These regressive changes become heavier and heavier, and the rate of diminution is greater, as compared with other three species.

In the adult fish consisting of one- and two-year-olds, the seasonal changes in the 
thymus are evident, and the peak thymic activity is reached in the period from May to June (Textfig. 3).

The thymic parenchyma of the juvenile fish caught in July to August is enlarged, $400-440 \mu$ in depth, while the specimens in October reduce to the half size (about $200 \mu$ ) of the thymus in the preceding period (Textfig. 3).

C. dolichognathus In the mature adult fish just in its breeding season (April) the thymic parenchyma is about $100 \mu$ in thickness, and is occupied mainly with the medium size lymphocytes. Frequently, the mitotic figures are encountered here and there. The thymus of the spent fish in June to July is packed with dense small lymphocytes, and reaches the highest thickness, 220 to $250 \mu$ (Pl. 1, Fig. 3). After that, the thickness decreases little by little, and is about $100 \mu$ in October (Pl. 1, Fig. 4). As stated above, seasonal changes in the thymus are detected in the adult fish, with a peak of activity in June to July (Textfig. 3).

The thymus of juvenile fish, 15 to $20 \mathrm{~mm}$ in body length, caught in July is $1.5 \mathrm{~mm}$ in length and $1 \mathrm{~mm}$ in depth. However, the thickness of parenchymatous tissue is enlarged, measuring about $300 \mu$. This thickness decreases gradually with the growth of fish. During winter season, the thymuses of both juvenile and adult fish are retained in the state of low activity (Textfig. 3).

[2] Monthly changes of frequency distribution of the body length of A. flavimanus and A. lactipes are illustrated in Textfig. 2. Unfortunately, no specimens inhabiting the sea were obtained. All individulas, 60 to $100 \mathrm{~mm}$ in body length, just at the time of
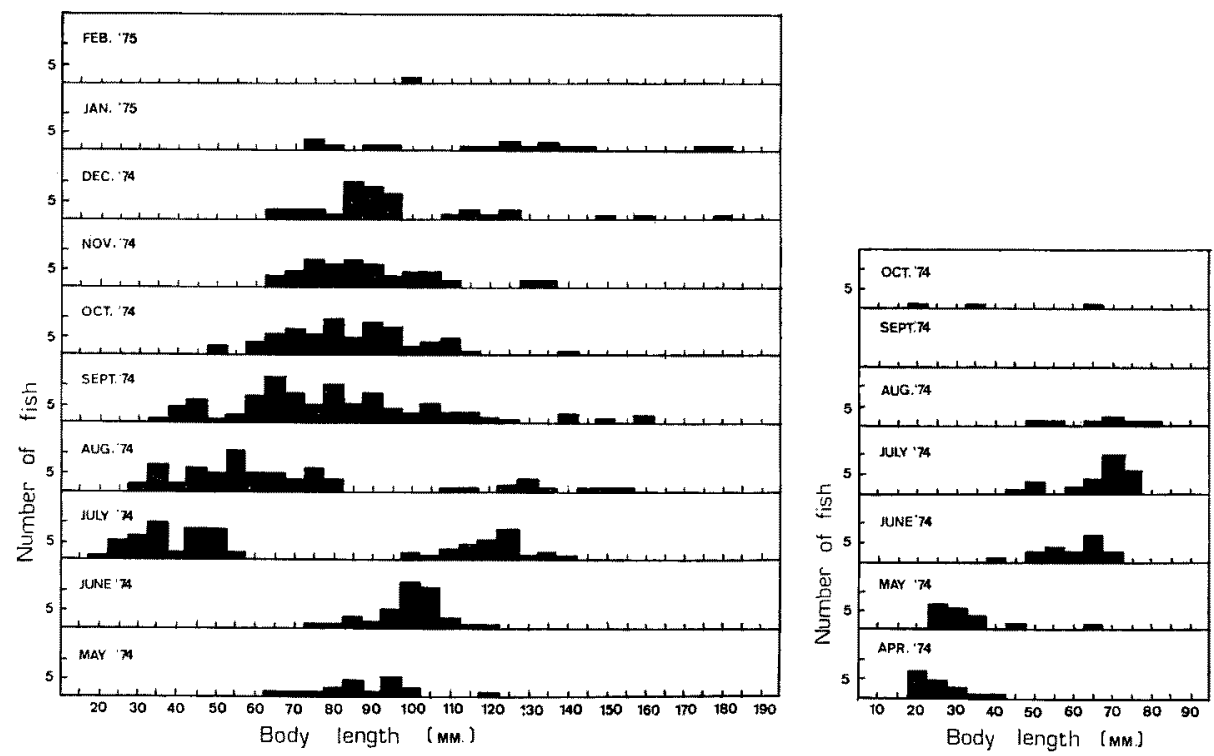

Fig. 2. Monthly change of frequency distribution of the body length of Acanthogobius flavimanus and A. lactipes, caught in the rivers of Murakami City facing the Japan Sea. 
ascending the river are spent in their gonadal condition. The fish caught in winter (January to February) at the mouth of the river has a testis in the state of active spermatogenesis. Therefore, it is very probable that the breeding season of A. flavimanus may extend from January to April. The juvenile fish, 20 to $50 \mathrm{~mm}$ in body length, are recognized from July. It may reach more than $65 \mathrm{~mm}$ in body length within one year.

On the other hand, the breeding season of $A$. lactipes may extend from June to August, and the individuals reaching more than $40 \mathrm{~mm}$ in body length have matured gonads. The juvenile fish, 25 to $35 \mathrm{~mm}$ in length, are obtained in October.

A. flavimanus The size of the thymus of $A$. flavimanus is large, and roughly comparable to that of $C$. gulosus. It measures $5 \mathrm{~mm}$ in length and $2.5 \mathrm{~mm}$ in depth in the adult fish. The thymic parenchyma of the spent fish caught in the river in June is packed densely with the small lymphocytes, and its depth reaches about $500 \mu$ (PI. 1, Fig. 5).

Hypertrophy of the epithelial cell (about $25 \mu$ in height) and follicular formation is seen in this time. A part of the cytoplasm has a positive affinity for AF and PAS reaction, and the residual material positive to AF is occasionally found in the lumen (PI. 1, Fig. 6). These features mentioned above are detected in two specimens of such month as June, August and September.

The structure closely similar to the Hassall's corpuscles consisting of circular zone is also seen (Pl. 2, Fig. 7). In August, the thymus of adult fish reduces its parenchymatous depth, and is just half size of that in June. This regressive change is more remarkable in September, measuring about $150 \mu$ (PI. 2, Fig. 8). The mast cells which appear in the diminutive time are demonstrated here and there (P1. 2, Fig. 9). In the specimen collected in February, sperm was seen in its testis, and the thymus was $150 \mu$ in depth. A number of the medium-sized lymphocytes are noticed in the thymus.

Though the specimens of March and April living in the sea were not collected, unfortunately, it is noted that the maximum hyperplasia of thymic parenchyma occurs May to June (Textfig. 3).

On the other hand, in the juvenile fish caught in July the thymic parenchyma is about $360 \mu$ in depth, and this value in that fish in August is about $300 \mu$, although its parenchyma is occupied fully with small lymphocytes. Thereafter, these small lymphocytes decreased gradually month by month (Textfig. 3 ).

A. lactipes The thymus of adult fish collected in June expected to be hyperplastic condition. Actually, however, the thymus is comparatively small, like that of $C$. dolichognathus, and $3 \mathrm{~mm}$ in length, $1 \mathrm{~mm}$ in width and $0.25 \mathrm{~mm}$ in depth. The parenchymatous tissue contains the dense small lymphocytes (P1. 2, Fig. 10).

A drastic decrease in the number of small lymphocytes occurs in the parenchymatous tissue of the thymus of the adult fish ( $71 \mathrm{~mm}$ in body length) caught in August. The size of parenchyma is $50 \mu$ in depth, $2 \mathrm{~mm}$ in length and $0.2 \mathrm{~mm}$ in height. Its shape is 


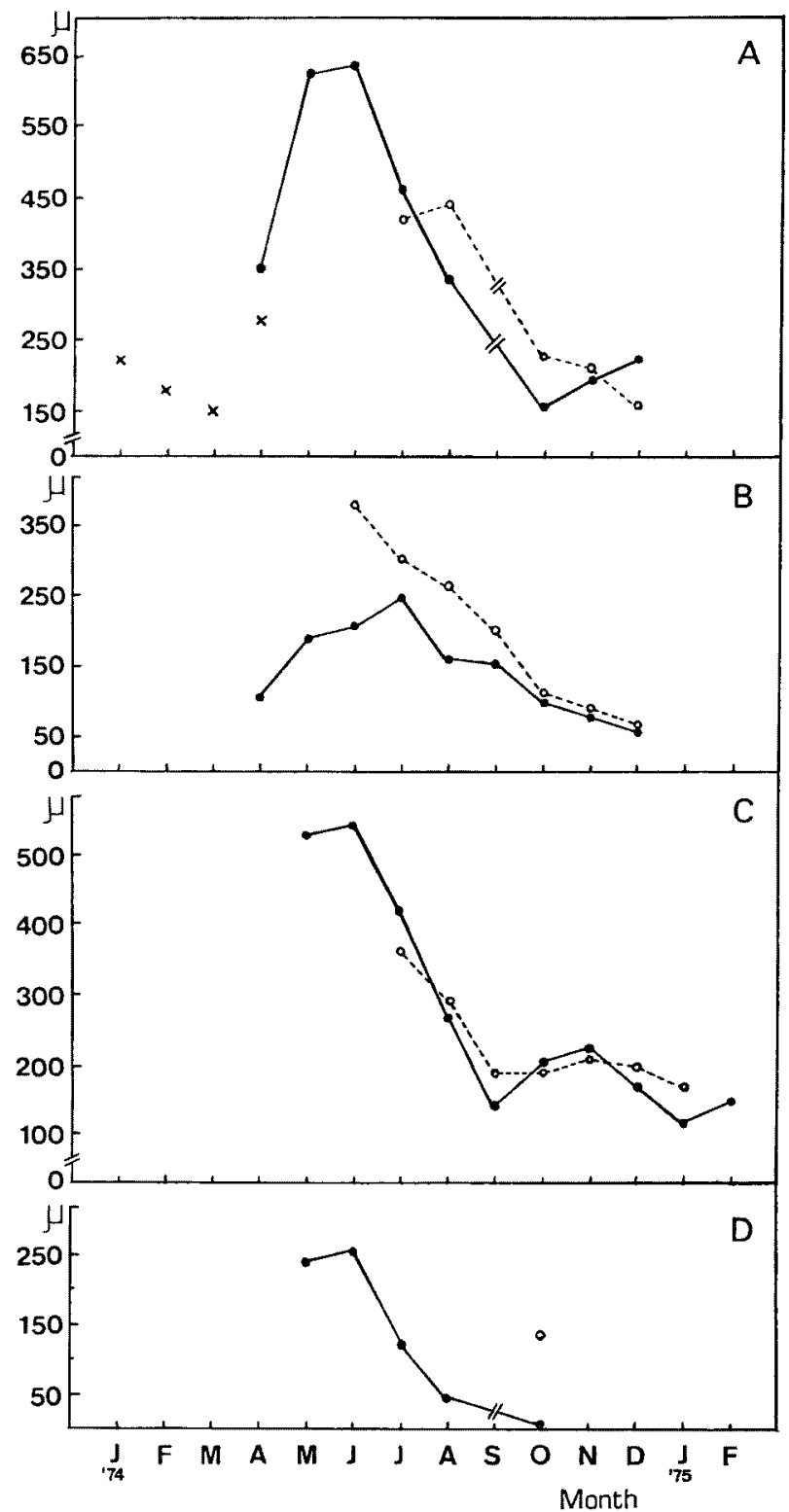

Fig. 3. Seasonal changes in the depth of the thymus in four species of gobiid fishes.

A. Chasmichthys gulosus, B. C. dolichognathus, C. Acanthogobius flavimanus, D. A. lactipes.

- 1 and 2 year old fish, ---- under-yearling, $O$ specimen of 1970.

slender and a thread-like structure by the naked eye. In the spent fish obtained in October, it is very difficult to see the lymphocytes, and the regression of the thymus itself is remarkable (Pl. 2, Fig. 11).

Regardless of the delayed breeding season (July to August) compared with those of 
other three species, the peak of thymic hyperplasia exists in May to June like other three species (Textfig. 3). However, the thymus of the juvenile fish caught in October is occupied entirely with small lymphocytes (PI. 2, Fig. 12).

\section{Discussion}

The heavy regression and further disappearance of the thymus after the time of sexual maturation have already been reported in the annual fish, such as Koayu (Plecoglossus) and ice-goby (Leucopsarion) and the Pacific salmon (Oncorhynchus) that die after spawning. ${ }^{1-2,6)}$ Such communications suggested the possible relationship between the loss of immunity and the spawning death. As stated briefly, on the other hand, in the char (Salvelinus) that can survive after spawning there was no regression in the thymus even in the sexual maturation. ${ }^{3)}$ Seasonal thymic change with a peak of activity in June to July was demonstrated in the flathead goby (Luciogobius) and forktongue goby (Chaenogobius), although there was a gradual change associated with the increasing age. It is of interest to see that the commencement of thymic activity occurs one to two months earlier than that in hemopoietic activity occurring in the periphery of the splenic artery and lymphoid tissue of the head kidney. Further, it was demonstrated that these cyclic changes in the lymphomyeloid tissues were quite in contrast and opposed to the activity of interrenal gland. ${ }^{4-5}$, These results mentioned above may suggested that there is an undiscovered function of the thymus in the adult fish other than immunity.

Even in the adult vertebrate animals, seasonal variations in the thymic activity were described in the association with the molting, hemopoiesis and other phases. ${ }^{7-10}$ ) MC ARDLE and ROBERTS ${ }^{11)}$ reported on the bilateral hyperplasia of the thymus in three-year-old rainbow trout. The possible relationship between the thymus and other endocrine glands, such as thyroid, islet of Langerhans, adrenal cortex and gonads, was pursued in several higher vertebrate animals., ${ }^{72-16}$ The role of the thymus as an endocrine gland that produces the thymosin remains as an unsettled problem. This problem is to be solved more precisely in relation to the function of lymphocytes. ROBERTSON et al. ${ }^{17}$ and $M C$ LEAY $^{18)}$ reported a decrease in the thymic lymphopoiesis of salmonid fish after the treatment with ACTH and hydrocortisone.

The present investigation using 4 species of gobies revealed that the thymic activities were not necessarily coincident with the breeding season. It is natural to say that the thymic activities of these gobies may be regulated by other factor, such as annual fluctuation of the time of daylight. Relationship between the photoperiodicity and the thymic activity has already been intimated in the Koayu (Plecoglossus) that is subjected to the controlled photoperiodicity, such as short or long photoperiod ( 8 hours light and 16 hours dark, or vice versa). In this experiment, thymic regression and final disappearance, ac- 
companying the acceleration of gonadal maturation, i.e., age involution, are one to two months earlier in the short-photoperiod group than in the control- and long-photoperiod groups. ${ }^{\text {" }}$

A remarkable degeneration of the thymus was also described in the Mexican characin (Astyanax) that were kept in the dark condition for one year or more. ${ }^{19)}$ At least, the pineal body of the lower vertebrates is considered to be the photoreceptive organ. In the rat, the pinealectomy provoked the involution of thymus and also lymphoid tissue, and conversely increase in the number of epithelial cells and the amount of connective tissue. ${ }^{20}$ Accordingly, it is necessary to elucidate the correlation between the thymic function and the photoreceptors, such as eye and pineal body, about the fish other than gobies used in this study. Similarly, more precise study is needed to clarify the possible effect of darkness on the thymus of fish.

As stated previously, the development of the thymus was accelerated well in the under-yearling gobiid fishes. ${ }^{2-3,5)}$ The present examination also revealed the relatively higher hyperplasia in the certain period of juvenile stage. Thereafter, regression occurred gradually month by month. Therefore, the rhythm of thymic activity of under-yearling fish differs from that of adult fish. It may be probable that the hyperplastic condition of the under-yearling fish is concerned largely with the establishment and manifestation of immunity.

MC ARDLE and RoBERTs ${ }^{11)}$ recognized the increase in the number of lymphocytes, formation of cord and gathering of the rosette of epithelial cells in the hyperplastic thymus of three-year-old rainbow trout. In addition, they also noticed the presence of Hassall's corpuscles and numerous acini. The present investigation revealed nearly identical pictures, such as the increase in the connective tissue of the vascular wall, Hassall's corpuscles, cystic formation of epithelial cells, and so on. These regressive changes gradually increase month by month. Moreover, the cells which gathered to form the cysts were positive to AF and PAS reactions. Increase in the number of Gomori-positive cells in the thymus of the rat was induced by treatment of testosterone as well as cortisol. ${ }^{12}$ Moreover, pinealectomy induced a decrease in the number of lymphocyte of thymus and conversely, an increase in the amount of connective tissue and multiplication of the epithelial cell. ${ }^{20)}$

Using immunofluorescence method, it was pointed that the thymosin might be produced in the epithelial cell of the thymus. ${ }^{21)}$ Thus, further detailed studies on the changes in the epithelial cells in relation to the activity of hemopoiesis are needed to elucidate the real role or function of the thymus of wild animals rather than laboratory ones.

\section{References}

1) Y. Honma and E. Tamura: This Bull., 38 995-1005 (1972). 
2) E. TAMURA and Y. Honma: ibid., 36, 661-669 (1970).

3) E. TAMURA and Y. Honma: ibid., 39, 1003-1011 (1973).

4) E. TAMURA and Y. HonMA: ibid., 40, 447-455 (1974).

5) E. TAMURA and Y. Honma: ibid., 41, 413-422 (1975).

6) O. H. Robertson and B. C. WeXLER: Endocrin., 66 222-239 (1960).

7) W. L. ANDERson: Condor, 72, 205-208 (1971).

8) G. Galleti and A. Cavallari: Acta Anat., 83, 593-605 (1972).

9) P. WARD and M. D. Kendall: Philosoph. Trans. Roy. Soc. London, B, 273, 55-64 (1975).

10) S. BaCchus and M. D. Kendall: ibid.. 273, 65-78 (1975).

11) J. F. MC Ardle and R. J. Roberts: J. Fish. Res. Bd. Canada 31, 1537-1539 (1974).

12) G. Csaba: Acta Biol. Acad. Sci. Hung., 23, 409-411 (1972).

13) G. Csaba P. Barath, and R. GiURGeA-JACOB: Endokrin,, 61, 271-275 (1973).

14) W. PIERPAolr and E. SorkIn: Experientia, 28, 851-852 (1972).

15) C. Bimes, P. De Graeve, S. Amiel et A. Gullhem: Anat. Histol. Embryol., 4, 162-171 (1975).

16) P. Sobhon and C. Jirasattham: Acta Anat., 89, 211-225 (1974).

17) O. H. Robertson, S. HANe, B. C. Wexler, and A. P. Rinfret: Gen. Comp. Endocrin. 3, 422-436 (1963).

18) D. J. MC LeAY: ibid., 21, $431-440$ (1973).

19) P. Rasquin and L. Rosenbloom: Bull. Amer. Mus. Nat. Hist., 104, 359-426 (1954).

20) G. CSABA and P. BARATh: Endocrin. Exp., 9, 59-67 (1975).

21) B. Mandi and T. Glant: Nature, New Biol., 246, 25 (1973). 


\section{Explanation of Plates}

Plate 1

Figs. 1-2. Chasmichthys gulosus, Figs. 3-4. C. dolichognathus, Figs. 5-6. Acanthogobius flavimanus.

Fig. 1a. A low power micrograph of the thymus of the adult fish caught just after spawning, to show the general feature of lymphocytes and follicular spaces. $\times 150$

b. Enlarged view of the follicular space and nearby structures. An increase in the amount of connective tissue elements is noticed. The specimen was fixed on June 10, $1974 . \quad \times 600$

Fig. 2. Thymus of the spent fish caught in October showing a remarkable diminution of the parencymatous tissue. $\times 150$

Fig. 3. Thymus of the adult fish caught just after spawning to show the dense small lymphocytes. The specimen was fixed on June 10, 1974. $\times 150$

Fig. 4. Thymus of the spent fish caught in October showing a remarkable diminution of the parenchymatous tissue. $\times 150$

Fig. 5. General view of the thymus of adult fish caught just after spawning (June), to show the dense small lymphocytes and a slight indication of follicular formation. $\quad \times 150$

Fig. 6. Enlarged view of the follicular lumen showing the residual material positive to AF stain. 600

Plate 2

Figs. 7-9. Acanthogobius favimanus, Figs. 10-12. A. lactipes.

Fig. 7. Enlarged view of a similar structure to the Hassall's corpuscle consisting of rounded epithelial elements. $\quad 600$

Fig. 8. Thymus of the spent fish caught in September to show the process of regressive change. $\times 150$

Fig. 9. Enlarged view of the thymus of the spent fish caught in August to show the mast cells scattered here and there. $\times 600$

Fig. 10. Thymus of adult fish caught in June showing the dense small lymphocytes and hyperplasia of the organ. $\times 150$

Fig. 11. Thymus of the spent fish caught in October showing a heavy degeneration. $\times 150$

Fig. 12. Thymus of the juvenile fish caught in October to compare with the picture of spent fish. Note the dense lymphocytes. $\times 150$

Figs. 1-5, and Figs. 7-12: Hematoxylin and eosin stain, Fig. 6: AF stain. 
Plate I

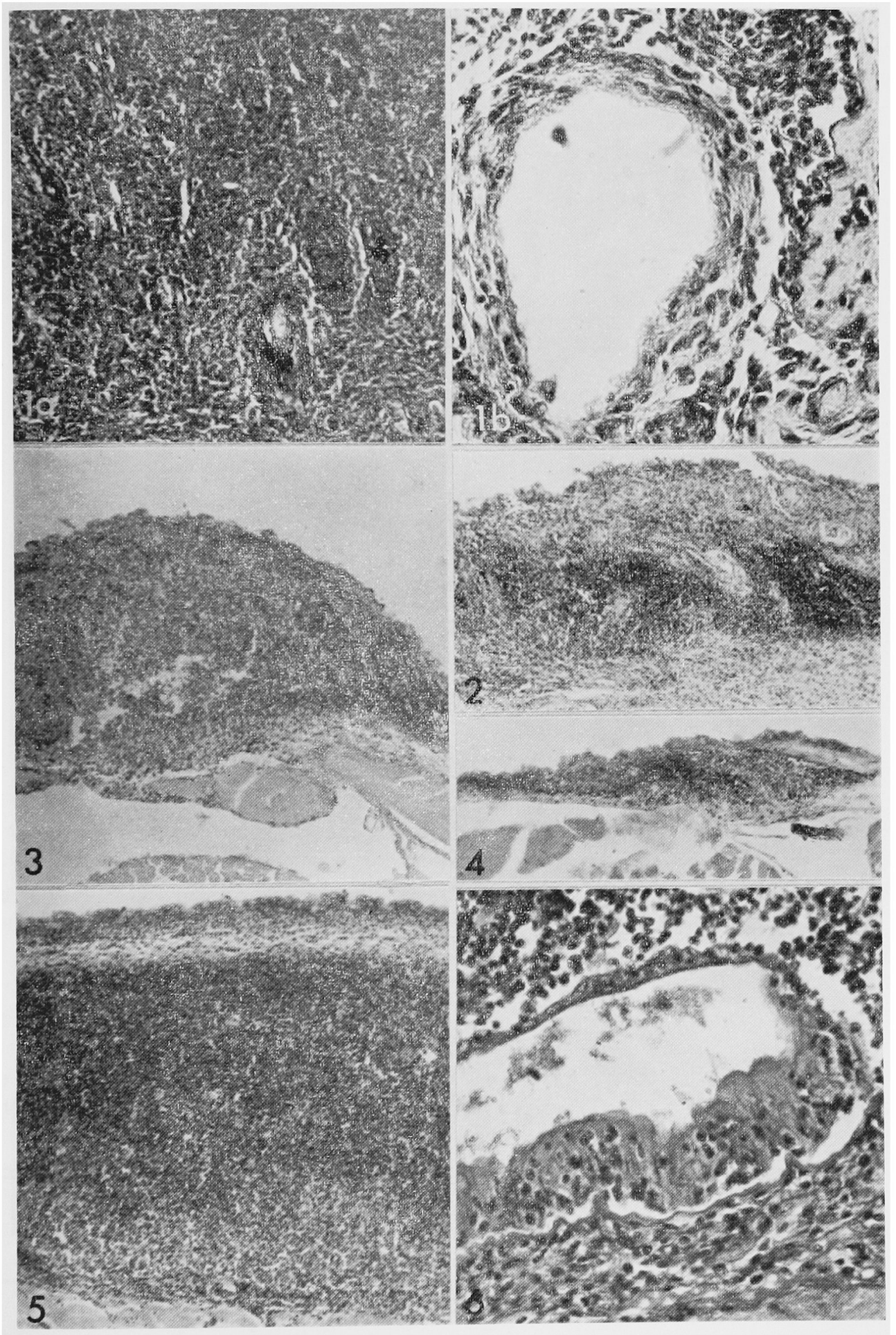


Plate II

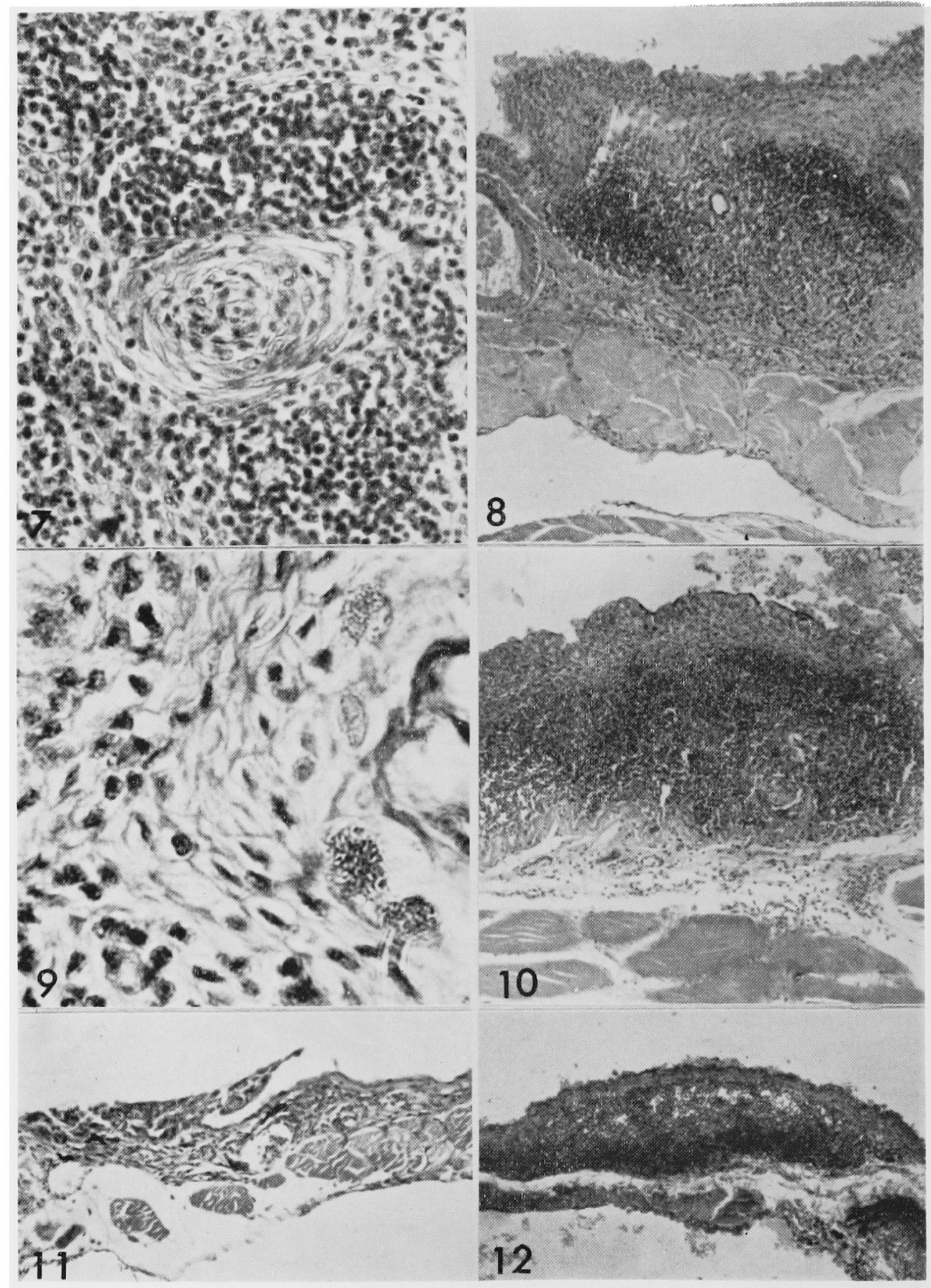

